\title{
SELF-RATED HEALTH AMONG WOMEN AND THEIR ASSESSMENT OF THE HEALTH CARE SYSTEM SAMOOCENA ZDRAVJA MED ŽENSKAMI IN NJIHOV ODNOS DO ZDRAVSTVENEGA SISTEMA V SLOVENIJI Mirjana Ule ${ }^{1}$, Slavko Kurdija ${ }^{1}$
}

Prispelo: 17. 10. 2012 - Sprejeto: 17. 1. 2013

Original scientific article

UDC 316.334:614

\begin{abstract}
Background: This article researches gender inequality in health based on subjective assessments of health, the accessibility of health care services and trust in the health care system between different social categories of women in Slovenia.

Methods: The study is based on the Slovenian Public Opinion survey (ISSP Health Module) carried out in 2011 on representative samples of the adult Slovenian population. In the data, we investigated the gender differences and difference between different socio-economic categories within the female sub-sample in self-assessed health, and some other related topics such as: trust in doctors, trust in health care system, access to health care services and attitude to the health care policy in Slovenia.

Results: The data shows significant inequalities in self-assessed health between different social strata. Self-assessed health is significantly lower among women at the bottom of the educational and income scale. The data also reveals strong support for the preservation of the available public health.

Conclusion: Neoliberal economic reforms (of health care) affect vulnerable social categories the most, and women are particularly exposed. The use of women's unpaid work in the family belongs among the basic (neo)liberal saving strategies. These want to take more care and health work within families from the shoulders of the state and place it onto the shoulders of family members, which mainly means women. In these circumstances, it is understandable that women subjectively assess their health as being worse than men's. Moreover, conditions are being established that de facto could lead to worse health in the female population in Slovenia.
\end{abstract}

Key words: subjective assessments of health, health inequality, gender/class differences, health policies

Izvirni znanstveni članek UDK 316.334:614

\section{Izvleček}

Izhodišče: Članek raziskuje spolne neenakosti v zdravju na osnovi subjektivnih ocen zdravja, dostopnosti do zdravstvenih storitev ter zaupanja $v$ zdravstveni sistem med različnimi socialnimi kategorijami žensk v Sloveniji.

Metode: Analiza temelji na raziskavi Slovensko javno mnenje (ISSP-modul zdravje), ki je bila izvedena $v$ letu 2011 na reprezentativnem vzorcu polnoletnih prebivalcev Slovenije. $V$ analizi smo proučevali razlike med spoloma in razlike med različnimi socialno-ekonomskimi kategorijami žensk $v$ samooceni zdravja ter pri nekaterih drugih sorodnih temah, kot so: zaupanje $v$ zdravnike, zaupanje $v$ zdravstveni sistem, dostop do zdravstvenih storitev in splošen odnos do zdravstvenega sistema $v$ Sloveniji.

Rezultati: Podatki kažejo močno povezavo med subjektivno oceno zdravja in socialno-ekonomskim položajem žensk. Slabo telesno in duševno zdravje se povezuje z nizkimi dohodki, nizko stopnjo izobrazbe, nižjimi družbenimi razredi. Podatki kažejo tudi močno podporo ohranjanju dostopnega javnega zdravja, kot ga poznamo v Sloveniji.

Zaključki: Neoliberalne ekonomske reforme (zdravstva) najbolj udarijo po ranljivih družbenih kategorijah; ženske so pri tem še posebej izpostavljene. Uporaba neplačanega dela žensk v družini sodi med osnovne neoliberalne varčevalne strategije. Te želijo čim več skrbstvenega in zdravstvenega dela $v$ družinah prevaliti z države na ramena družinskih članov, kar pomeni predvsem žensk. V takšnih okoliščinah je razumljivo slabše subjektivno ocenjevanje 
zdravja pri ženskah. Še več, gre za vzpostavljanje pogojev, ki tudi realno lahko vodijo v slabše zdravje ženskega prebivalstva $v$ Sloveniji.

Ključne besede: subjektivna ocena zdravja, neenakost v zdravju, spolne/razredne razlike, zdravstvene politike

\section{INTRODUCTION}

The aim of this article is to research gender inequality in health based on subjective assessments of health, health problems, the accessibility of health care services and trust in the health care system in different social categories of women in Slovenia. The conventional wisdom is that women live longer than men but experience more morbidity (1). Recent reviews have argued that this is an oversimplified picture (2). While research reports that universally females experience longer life expectancy than males, there is less uniformity in reports of morbidity differences. Morbidity data tells of the incidence of the range of problems that men and women experience coping with their daily lives $(3,4)$.

Namely we need to distinguish between objective indicators of inequalities on the one hand, and people's subjective sense of inequalities (5) on the other. We assume that these two sets of indicators do not necessarily coincide. Differences in the subjective assessment of health can turn out to be even bigger than differences according to objective indicators (6, 7). Subjective feelings are based upon the subjective comparisons of notions about previous standards and life experiences, upon the perceptions of the current situation as well as upon the expectations for the future. Perceived health problems differ from other sources of knowledge about women's health such as official health statistics; perceptions are based on an individual's interpretation of health information and their own experiences (4). Subjective health refers to how individuals evaluate their own health status. People with subjective poor health are those who perceive themselves as ill.

Lay perceptions of women's health have been criticized for being too subjective. However, with the growth of the women's health movement and feminist research methodologies, there is increasing recognition of the validity of women's perceptions of their health problems. Researchers argue that women themselves are indeed in the best position to determine the health problems that contribute to their quality of life (4). While it is true that subjective perceptions of illness are not necessarily always a sign of a medical condition, they represent a disturbance and an impediment in everyday life, as they stem from one's everyday activity (8-10). In their analysis of stress, tiredness and anxiety in women's lives, Denton and Walters (4) identified these problems to be greater for: women who have children under 16 and who are overburdened with work inside and outside the home (especially in something other than a white collar job). Women in these categories are more likely to have problems finding time for themselves, to have poor relationships with a husband, partner or another family member, or problems related to caring for a sick or older relative, and to experience money problems or concerns with parenting and children's health. Experiencing illness is a markedly social evaluation concept referring to changes in the experiencing, practices and social relations of individuals in their everyday lives (8). While physical illness is defined by neutral biological criteria, the experience of illness is essentially social, referring to an undesired deviation from the accepted social norms of health, acceptable behaviour and action. Experiencing and understanding health and illness corresponds to an individuals' everyday experience of their bodies and is pivotal for their self-image or body identity (11).

Another important indicator of social inequality in health is the assessment of the accessibility of health services. While this is perhaps not the most important indicator for the subjective feeling of health, it is important for planning social policies. Moreover, the burden of paying for health services is increasingly figuring as a factor in poverty, particularly for socially vulnerable groups, and is among the key factors creating a special responsibility for the health care sector by giving it an opportunity to provide efficient answers (12). Access to health services can be economic, geographic and cultural with accessibility usually referring to economic accessibility, i.e. health services accessible in the same way to all population groups. This form of accessibility is provided by the free public health care service organised through the compulsory health insurance system for the whole population. Geographic accessibility is provided by the dispersion of health care services throughout the country and their physical accessibility (13). When asked about accessibility, the respondents usually thought of economic and geographical accessibility, while for cultural accessibility they referred to acceptance and respect. The indicator of cultural accessibility is the access of marginal groups to suitably adapted information on their health. That is, 
there are differences in the attention received. Namely patients from less privileged environments receive less attention, which leads to differences in the quality of care and attention they obtain.

One of the indicators of women's attitude towards the health care system is also trust in it. Trust is a widely used notion indicating positive expectations regarding the actions of other individuals, groups, institutions or social systems (14). The regulation of the doctor-patient relationship cannot completely eradicate the patient's uncertainty, risks and vulnerability. Therefore, a certain degree of trust in the doctor is necessary for a patient to be able to satisfy his or her health care needs.

The variations in medical and lay perspectives of women's health problems indicate that we must rely on many different types of data in seeking to understand women's health (15). Each represents a different social construction of what constitutes health and illness. While it is important to document that women's health concerns differ from men's, it is equally important to recognize the variation of inequality among women. These differences are socially produced and unjust $(16,6)$. Within the approach that emphasises the role that social class and other social structural factors play in disease causation, two different types of explanation can be clearly identified (17). First, there are the explanations that impute a direct link between social and economic circumstances and health outcomes. Secondly, there are the explanations that connect social and economic circumstances and health outcomes through behaviour. Explanations for these social class differences in patterns of health behaviour have emphasised the importance of both structural and cultural factors.

Table 1. 5 factor model; total explained variance 65.9\%; extraction method: principal component analysis; rotation method: varimax with Kaiser normalization.

Tabela 1. Model s 5-imi faktorji, skupna pojasnjena varianca 65,9\%; metoda glavnih komponent; rotacija: varimax.

\begin{tabular}{|c|c|c|c|c|c|}
\hline $\begin{array}{l}\text { Variables in the model/ } \\
\text { Spremenljivke v modelu }\end{array}$ & $\begin{array}{l}\text { Trust in } \\
\text { health-care } \\
\text { system/ } \\
\text { Zaupanje v } \\
\text { zdravstveni } \\
\text { sistem } \\
\end{array}$ & $\begin{array}{l}\text { Mental } \\
\text { health/ } \\
\text { Psihično } \\
\text { zdravje } \\
\end{array}$ & $\begin{array}{l}\text { Physical } \\
\text { health/ } \\
\text { Fizično } \\
\text { zdrvaje }\end{array}$ & $\begin{array}{l}\text { Trust in } \\
\text { doctors/ } \\
\text { Zaupanje } \\
\text { v } \\
\text { zdravnike }\end{array}$ & $\begin{array}{l}\text { Accessi } \\
\text { bility/ } \\
\text { Dostopnost }\end{array}$ \\
\hline$\%$ of explained variance & $15,8 \%$ & $15,0 \%$ & $14,5 \%$ & $10,3 \%$ & $10,3 \%$ \\
\hline $\begin{array}{l}\text { How much confidence do you have in the health care system in } \\
\text { Slovenia?/ Koliko zaupate... zdravstvenemu sistemu v Sloveniji }\end{array}$ & 0,80 & & & & \\
\hline $\begin{array}{l}\text { Would you say that the health care system in Slovenia needs } \\
\text { changes?/ Ali menite, da zdravstveni sistem v Sloveniji potrebuje } \\
\text { spremembe? }\end{array}$ & 0,76 & & & & \\
\hline $\begin{array}{l}\text { In general, the health care system in Slovenia is inefficient./ V celoti } \\
\text { gledano je zdravstveni sistem v Sloveniji neučinkovit. }\end{array}$ & $-0,73$ & & & & \\
\hline
\end{tabular}

This analysis is based on the Slovenian public opinion survey fielded in $2011(\mathrm{~N}=1082)$ (18). The survey also contained the Module on Health - made within the international ISSP project (International Social Science Program) (19). The Module on Health includes a broad panel of questions addressing the social aspects of health. The basic research goal was to look for differences (inequalities) between men and women, and between different categories within the female sub-sample in self-assessed health. Beside the basic dependent variable 'How good is your health in general?' for self-assessed health, the survey includes a set of variables that measure self-assessed physical and mental health.

To discuss the problem of health inequalities more broadly, a larger number of indications linked to the attitude towards the health care system were included in the analyses - trust in health care as a system, trust in doctors and the assessment of access to health care services. The ISSP Module on Health allows us to add a large number of indications linked to the attitude towards the mentioned topic, so we decided to test the data reduction model using factor analysis to identify homogenous, content dimensions (confirmed with the factors analysis). Analysis of the entire set of variables has confirmed the creation of five substantive dimensions. Based on this, we defined five key indexes: mental health, physical health, trust in the health-care system, trust in doctors and accessibility. 


\begin{tabular}{|c|c|c|c|c|c|}
\hline $\begin{array}{l}\text { Variables in the model/ } \\
\text { Spremenljivke } v \text { modelu }\end{array}$ & \begin{tabular}{|l|} 
Trust in \\
health-care \\
system/ \\
Zaupanje v \\
zdravstveni \\
sistem \\
\end{tabular} & $\begin{array}{l}\text { Mental } \\
\text { health/ } \\
\text { Psihično } \\
\text { zdravje }\end{array}$ & $\begin{array}{l}\text { Physical } \\
\text { health/ } \\
\text { Fizično } \\
\text { zdrvaje }\end{array}$ & $\begin{array}{l}\text { Trust in } \\
\text { doctors/ } \\
\text { Zaupanje } \\
\text { v } \\
\text { zdravnike }\end{array}$ & \begin{tabular}{|l} 
Accessi \\
bility/ \\
Dostopnost
\end{tabular} \\
\hline $\begin{array}{l}\text { In general, how satisfied or dissatisfied are you with the health care } \\
\text { system in Slovenia?/Kako ste nasploh zadovoljni ali nezadovoljni } \\
\text { z zdravstvenim sistemom v Sloveniji? }\end{array}$ & 0,66 & & & & \\
\hline Have you lost confidence in yourself?/Ste izgubili zaupanje vase? & & 0,89 & & & \\
\hline $\begin{array}{l}\text { Have you felt you could not overcome your problems?/Ste imeli } \\
\text { občutek, da ne morete premagati svojih težav? }\end{array}$ & & 0,87 & & & \\
\hline $\begin{array}{l}\text { Have you felt unhappy and depressed?/Ste se počutili nesrečne } \\
\text { in depresivne? }\end{array}$ & & 0,81 & & & \\
\hline Have you had bodily aches or pains?/Ste imeli fizične bolečine? & & & 0,79 & & \\
\hline $\begin{array}{l}\text { Do you have a long-standing illness, a chronic condition, or a } \\
\text { disability?/ Ali imate dolgotrajn obolezen, kronične težave ali } \\
\text { invalidnost? }\end{array}$ & & & $-0,74$ & & \\
\hline $\begin{array}{l}\text { Have you had difficulties with work or household activities because } \\
\text { of health problems?/Ste imeli težave pri delu v službi ali pri domačih } \\
\text { opravilih zaradi zdravstvenih težav? }\end{array}$ & & & 0,72 & & \\
\hline $\begin{array}{l}\text { In general, would you say your health is...?/Kaj bi nasplošno rekli, } \\
\text { ali je vaše zdravje ...? }\end{array}$ & & & 0,71 & & \\
\hline $\begin{array}{l}\text { The medical skills of doctors are not as good as they should be.l } \\
\text { Medicinsko znanje zdravnikov ni tako kakovostno kot bi moralo biti. }\end{array}$ & & & & 0,82 & \\
\hline $\begin{array}{l}\text { Doctors care more about their earnings than about their patients./ } \\
\text { Zdravnike bolj skrbi zaslužek kot pa bolniki. }\end{array}$ & & & & 0,70 & \\
\hline $\begin{array}{l}\text { All things considered, doctors can be trusted./ } \mathrm{V} \text { celoti gledano } \\
\text { lahko zdravnikom zaupamo. }\end{array}$ & & & & $-0,57$ & \\
\hline $\begin{array}{l}\text { If you become seriously ill, you would get ... treatment from the } \\
\text { doctor of your choice? V primeru, da bi resno zboleli, kakšna } \\
\text { je verjetnost, da bi dobili... možnost zdravljenja pri zdravniku po } \\
\text { lastni izbiri? }\end{array}$ & & & & & 0,87 \\
\hline $\begin{array}{l}\text { If you become seriously ill, you would get... the best treatment } \\
\text { available in Slovenia?/ V primeru, da bi resno zboleli, kakšna } \\
\text { je verjetnost, da bi dobili... najboljše razpoložljivo zdravljenje v } \\
\text { Sloveniji. }\end{array}$ & & & & & 0,81 \\
\hline
\end{tabular}

Source: Slovenian public opinion survey (18).

Vir: raziskava Slovensko javno mnenje (18).

Since all the factor loadings are relatively strong, we decided to compose 5 index indicators (corresponding to 5 factors). Indexes are the respondent's summed scores on factor-defined variables. They were constructed as sums of points of clearly expressed opinion on variables that constitute the indexes (e.g.: "very important" + "important", "strongly agree" + "agree", etc.). In this way, we tried to observe the relationship between five indexes (factors) and different socioeconomic indicators. The key independent variables were education, net personal income, self-defined class position, age, region and nationality. Education was re-coded into four categories (primary education level, vocational education level, secondary education level, high education level), while income was divided into quartiles for the total sample (up to 350 EUR, 350-600 EUR, 600-900 EUR, over 900 EUR). The self-defined class position was another important independent variable with the following four categories: working class, lower middle class, middle class and upper middle class. For nationality, we took two categories: Slovenian nationality and other nationalities. The region was also defined by two categories: Slovenia - West, Slovenia - East. Age was classified into four basic categories: aged 18 to 30 years, 31 to 45 years, 46 to 60 years and 61 years old and above.

The final part of the article focuses on the overall image of the general attitudes toward the public health care system in Slovenia. 


\section{RESULTS}

\subsection{Differences in self-rated health between genders and between women according to their socio-economic status}

In Figure 1, the results of five indexes are compared by gender and, within the female sub-sample, in structure. The most pronounced gender differences are shown in subjective health assessments. Subjective assessment of physical health and mental health show significantly worse health among women. This is especially significant in the case of physical health. This difference is crucial for understanding the phenomenon of gender inequality in health. Significant differences between the genders (which, however, is not as pronounced as in health assessment) has also been shown in the case of trust in doctors. Contrary to that, we cannot find a significant gender difference in the assessment of access to health care services, and in the case of trust in the health care system.

Even greater than the differences between the sexes are the differences within the female population. The differences within the female sub-sample are shown in Figure 2.

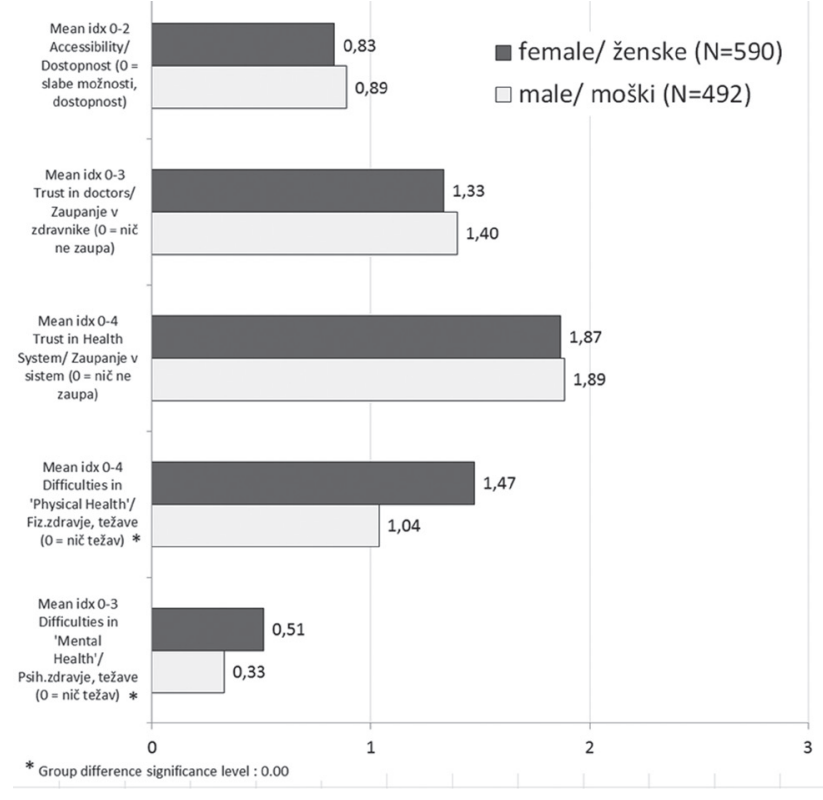

Figure 1. Difference in means in a 5-index model by gender $(N=1082)$.

Graf 1. Razlike v povprečjih pri 5-ih indeksih glede na spol ( $N=1082)$.

Source: Slovenian public opinion survey (18).

Vir: raziskava Slovensko javno mnenje (18).

A comparative analysis of the subjective assessment of physical health problems (Figure 2) shows considerable social inequalities in health between the different social categories of women in Slovenia. Statistically significant are differences in education, income, age and social stratum. The biggest share of difficulties in physical health is reported by women with a low education and low income (from EUR 350 to EUR 600), i.e. working class women. As expected, the range of physical health difficulties increases with age. Statements about difficulties with physical health systematically decrease with a higher social class, among women with a higher income and a higher education. Regarding the geographical position, women from Eastern Slovenia (recording a higher poverty rate and unemployment) report a slightly larger share of physical health difficulties. The subjective assessment of mental health is also the worst among socio-economically deprivileged groups of women. The biggest share of health difficulties is reported by women who have an elementary or vocational education, those with a low income as well as working class and lower middle class women. There are, however, some differences if the mental health assessments are compared to the physical health assessments. More mental health difficulties are reported by women with a low income (up to EUR 350), women aged 31-45 and, in terms of class typology, lower middle class women. This is also shown by other research studies. 


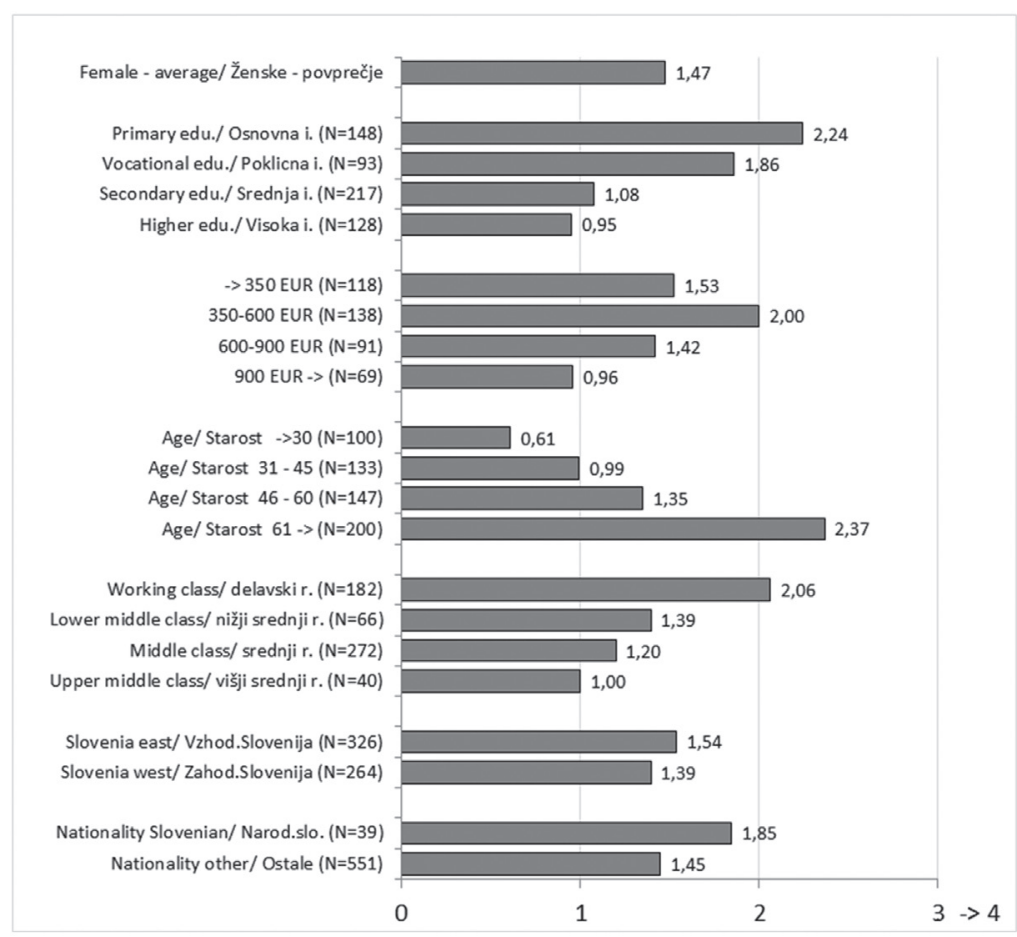

Figure 2. Index: difficulties in ,physical health'/female subsample $(N=590) /$ mean on score $0-4 / 0=$ no problems. ${ }^{1}$ Graf 2. Indeks: fiz. zdravje - težave/ podvzorec žensk ( $N=590) /$ povprečje na indeksu 0-4/ $0=$ nič težav.

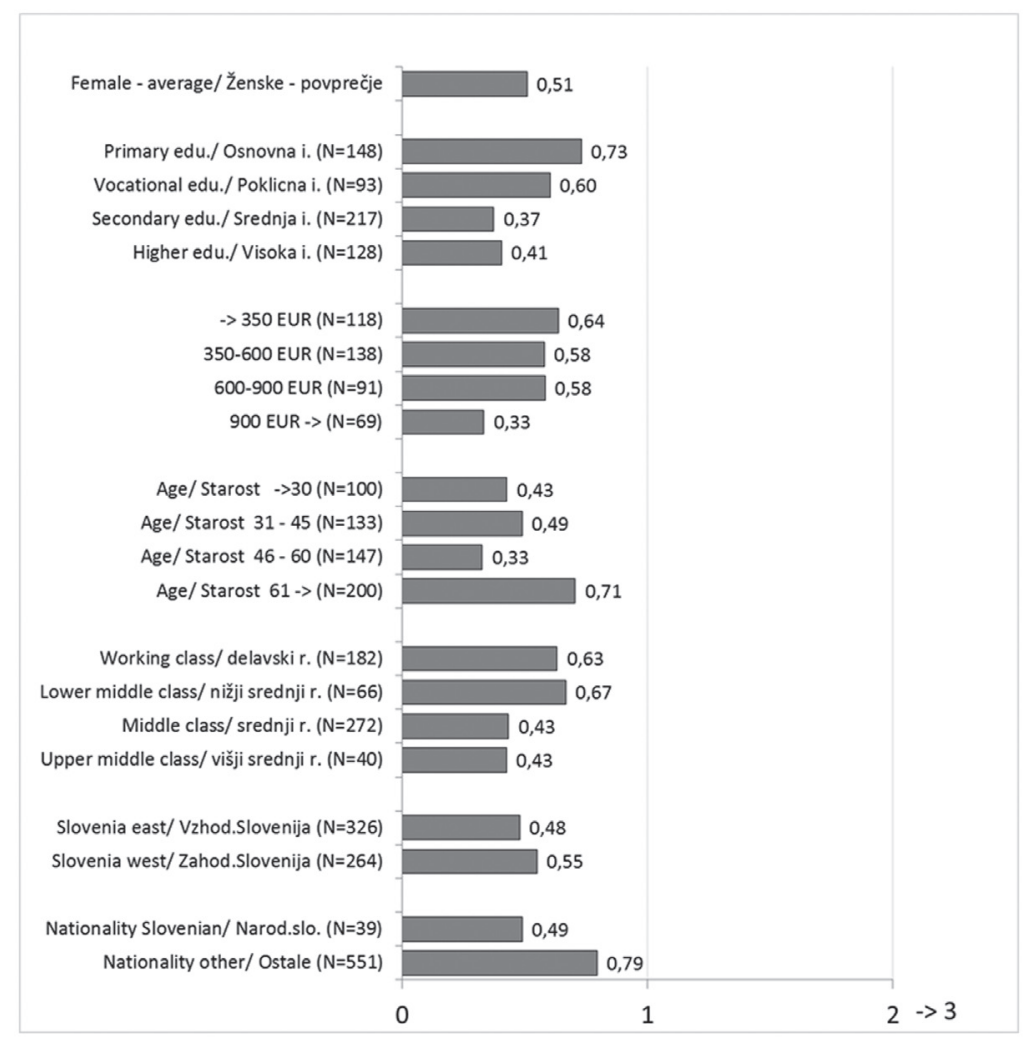

Figure 3. Index: difficulties in , mental health'/female subsample ( $N=590) /$ mean on score $0-3 / 0=$ no problems. ${ }^{2}$ Graf 3. Indeks: psih. zdravje - težave/ podvzorec žensk ( $N=590) /$ povprečje na indeksu 0-3/ $0=$ nič težav. 


\subsection{Differences in the subjective assessment of accessibility to health care services between women}

The assessment of accessibility shows some differences relative to the women's socio-economic positions. Although these differences are not so significant, we can see that a linear growth in assessed accessibility is shown with increasing levels of education. A similar relationship is shown in income. The most pronounced difference appears in the case of self-defined social classes. By far the greatest level of accessibility is reported by women from a higher class.
Studies and research across the world show that attitudes to and the approach taken by health care suppliers change according to the client's gender, education, class etc. Those who have access to quality health services are often deemed by health practitioners as being "worthier of being treated «, while those without such access are often deemed »less worthy «. A just social policy system should be organised to recognise »the common humanness of different groups and the equal worth of all people« (13).

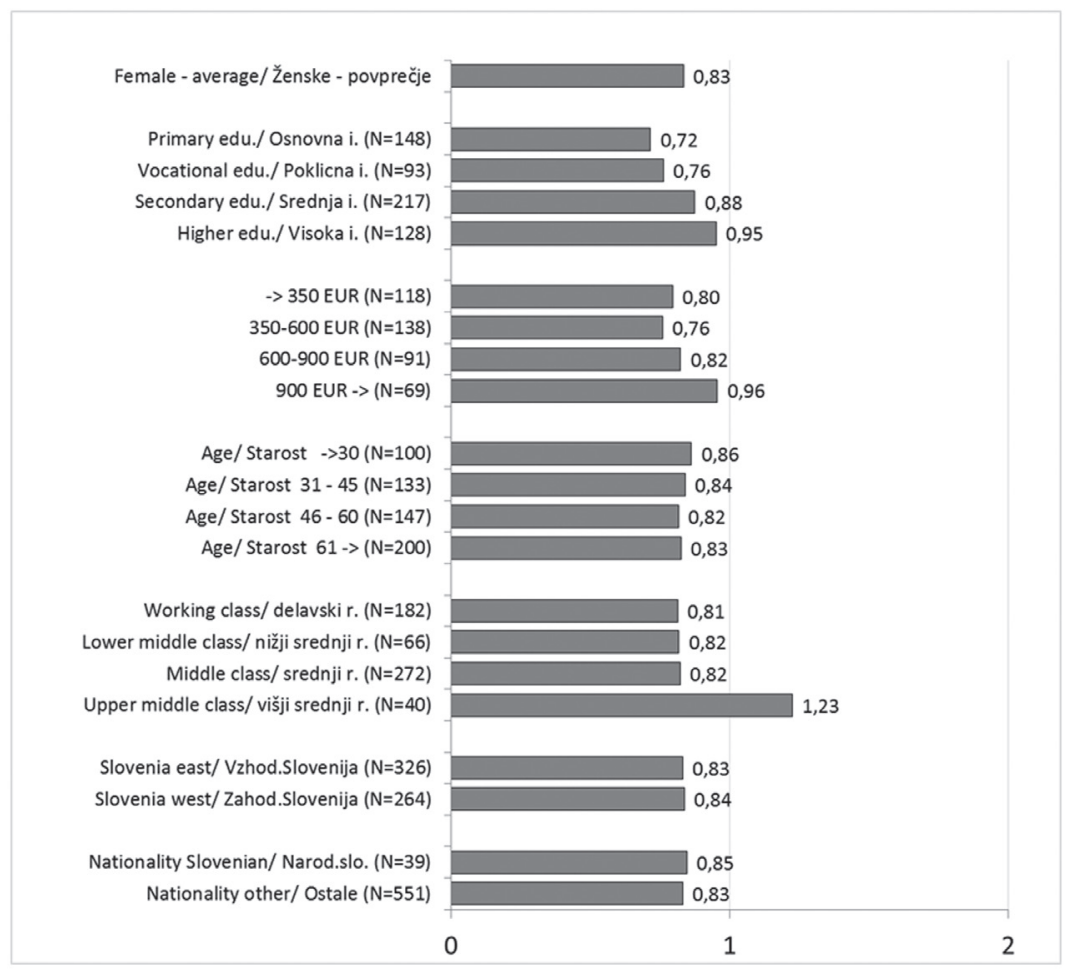

Figure 4. Index: accessibility / female subsample $(N=590) /$ mean on score $0-2 / 0=$ poor access. ${ }^{3}$ Graf 4. indeks: Dostopnost/ podvzorec žensk $(N=590) /$ povprečje na indeksu 0-2/ $0=$ slab dostop.

\subsection{Trust in doctors and the health care system among women in Slovenia}

Trust was tested in two ways, i.e. through trust in doctors and trust in the health care system. The responses show a relatively high and unified degree of trust in doctors. Yet there are also certain differences regarding the socio-economic position of women, although they are far less expressed than those in the previous presentations. Easily the greatest degree of trust is reported by women from a higher class. This can also be understood as the result of them having better access and receiving higher quality care, which can reduce insecurity and increase trust among this category of women.

In measuring trust in the health care system, stratification differences were not as big as in the subjective assessment of health. 


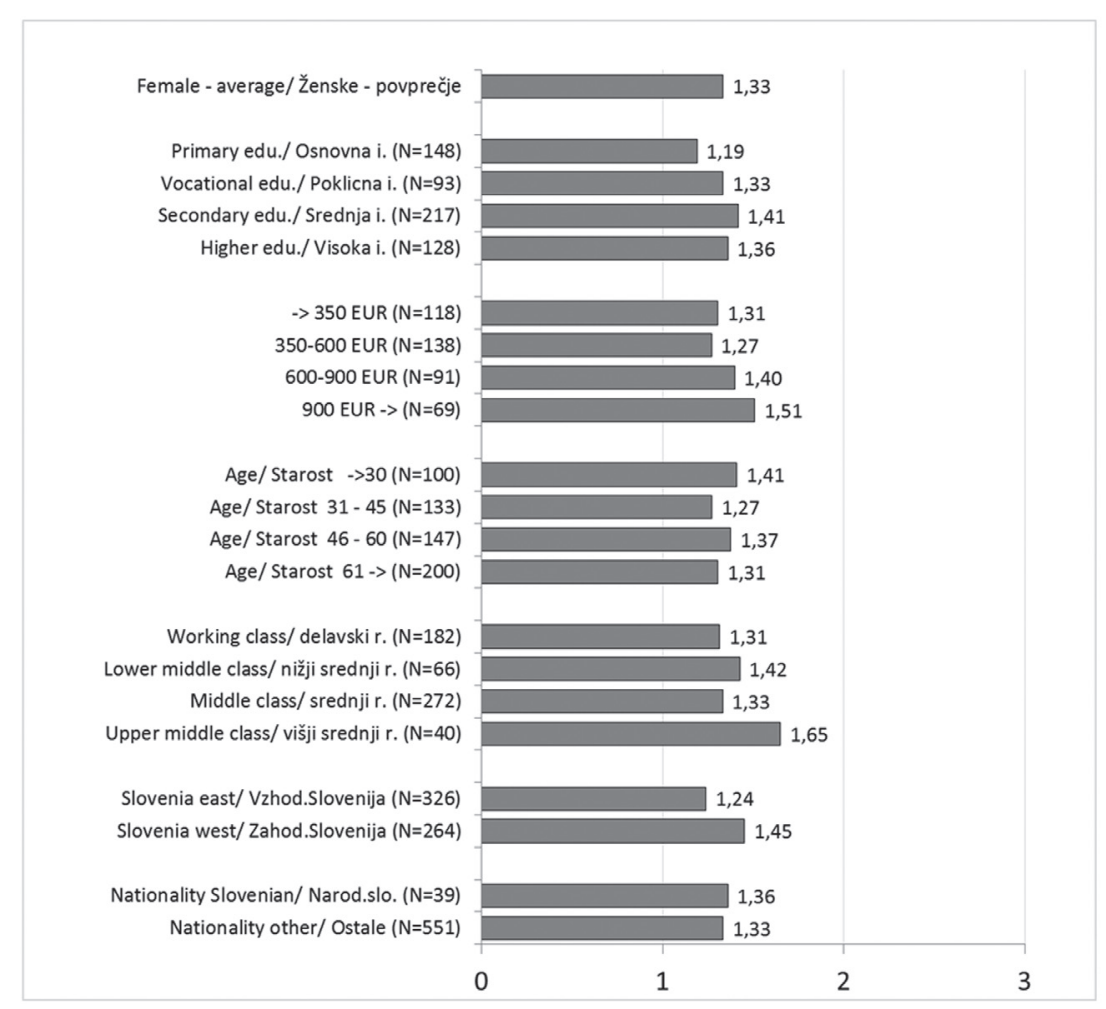

Figure 5. Index: trust in doctors / female subsample $(N=590) /$ mean on score $0-3 / 0=$ no trust. ${ }^{4}$

Graf 5. indeks: Zaupanje v zdravnike/podvzorec žensk ( $N=590) /$ povprečje na indeksu 0-3/0= ni zaupanja.

The highest degree of trust in the health care system is stated by the women with the lowest education, lowest income, working class women, women aged over 61, and women from the highest social stratum. How can this be explained? Modern systems like the health care system are too complex for individuals to be able to get to know and understand in detail, so they simply have to trust them. If insecurity is unacceptable in other domains, it is even more so during illness, which is terrifying enough in itself. Therefore, trust in the health care system, which has been systematically perceived by public opinion studies in Slovenia, is the product of the absence of direct control and defence against heart-wrenching insecurity. However, a high degree of trust is also the result of fearing a change for the worse, particularly in those categories that would fare the worst under circumstances of greater privatisation and commercialisation of health care. 


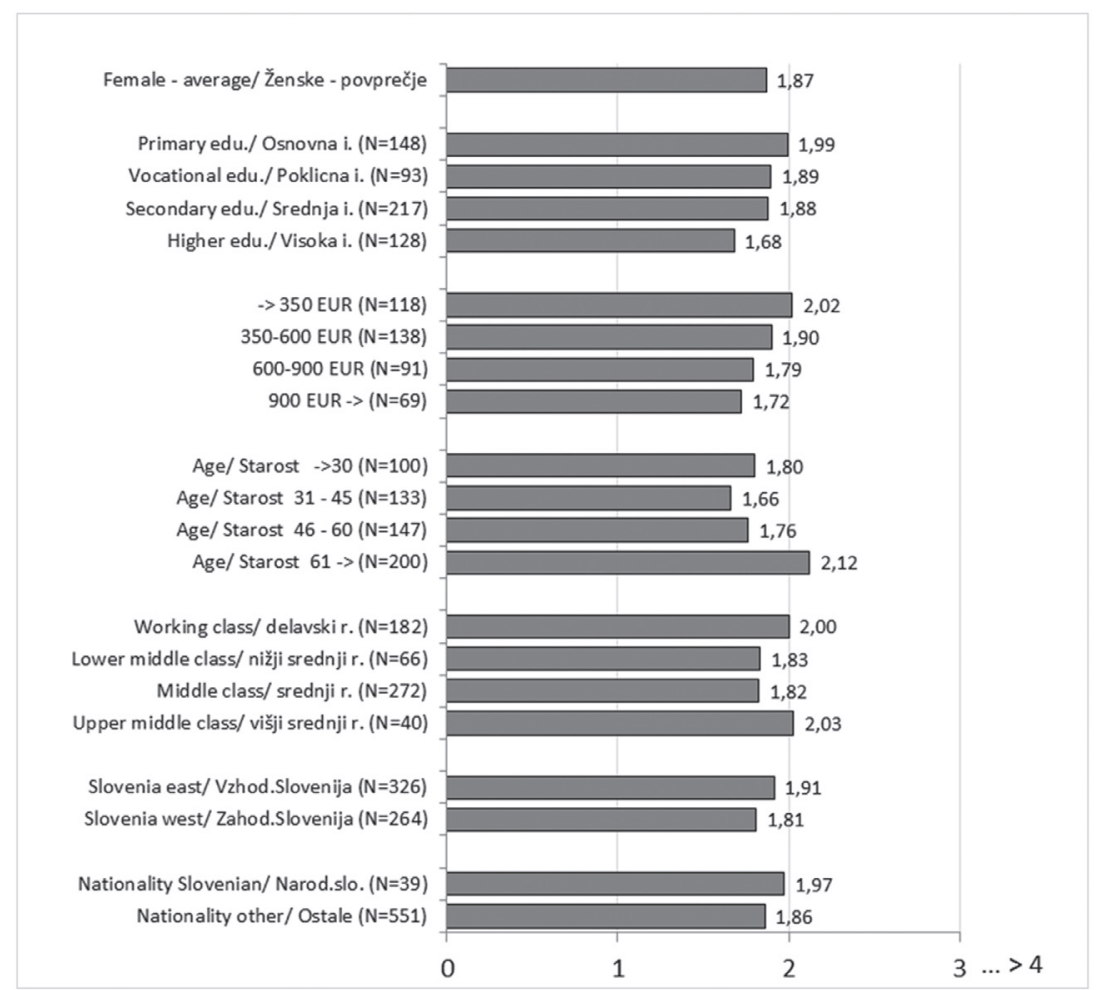

Figure 6. Index: trust in the health system / female subsample $(N=590) /$ mean on score $0-4 / 0=$ no trust. ${ }^{5}$ Graf 6. indeks: Zaupanje $v$ sistem/ podvzorec žensk ( $N=590) /$ povprečje na indeksu 0-4/ 0= ni zaupanja.

\section{DISCUSSION}

The analyses presented here corroborates our initial thesis that there are significant differences in the subjective assessment of health between men and women in Slovenia, with even greater differences existing within the female population. The aim is to draw attention to understanding and perception of the affordable public health care system as a kind of historical value in Slovenia, which enjoyed and still enjoys a relatively high level of trust.

The data shows that the subjective assessment of physical and mental health, accessibility to health services and trust in doctors reports systematically lower scores among women with a lower education, income and class.

The data shows a strong correlation between the subjective perception of health and the socio-economic status of women. Poor physical and mental health has been linked to a low income, low levels of education, working class and other indices of disadvantage. The data has also shown that problems identified by government statistics and medical experts do not necessarily correspond to the health problems identified by women themselves. To fully understand women's health, it must be recognized that health is determined by both contextual factors and the structural sources of women's lives. The subjective health status is highly dependent on the cultural, socio-economic and even political context.

Psycho-social explanations of differences in subjective assessments of women's health in Slovenia emphasise the decisive impact of stressful living conditions in women with a lower social position. Some researchers (20) have posited that socio-psychological mechanisms may be part of the explanation for the fact that socioeconomic inequalities run right through the social spectrum in wealthy societies. They argued that the polarised income distributions within countries have a negative impact on stress, self-esteem and social relations which, in turn, impact physical well-being. How people experience and perceive inequalities is central to this thesis (21). Not only are life problems unequally distributed among the social groups and communities, but the capabilities to solve these problems are also clearly unequally distributed.

However, unjustified generalisations from these findings should be avoided. Frequently monocausal 
deductions, such as that individuals fall in a lower social stratum because they do not master the appropriate strategies to cope with situations of crisis or stress, try to justify the lower stratum's increased affectedness by stressful events than the middle or high strata's. Such a deduction is yet another version of looking for "justifications « for the class division of society in the different »capabilities people possess «. The opposite assumption is more justified, namely that the unequal distribution of "coping strategies « in different social strata and groups occur due to the unequal life strains in crisis situations in different social strata. Generally, women in Slovenia still typically experience greater care and responsibility strains in everyday family life and survival, which is why they are more affected by the worsening living conditions in the conditions of crisis.

Some research has suggested that it is not just absolute levels of socio-economic deprivation that affect people's health, but also relative deprivation - in other words where we see ourselves in relation to others $(22,9,17$, 16). The discussions amongst people living in poorer circumstances and more deprived areas showed that they were very much aware of the effect of their relative poverty on health $(22,16)$. Many of them expressed anger and frustration when talking about their experiences of living in an unequal society.

When we run out of rational and institutional guarantees of security, the only thing left is trust. This can explain the trust in the health care system found amongst the lowest social categories of women. Women living in the worst socio-economic conditions give the worst assessments of their own physical and psychological health and are the most constrained when it comes to access to health care services, while at the same time they express a high degree of trust in the health care system. They mainly see security in the efficient and just nature of the public health care system. Thus, in response to the question $/ / s$ it just or unjust that people with a higher income can afford better health care than people with a lower income? «, up to $83 \%$ of the respondents replied that it is unjust.

Insecurity also feeds on a fear of the disintegration of the public health care system. The existence of this fear is also shown by the respondents response to the statement given in the research, i.e.: " The health care system in Slovenia will improve «, with only $21 \%$ of respondents agreeing. Up to $42 \%$ disagreed with the statement. Although a slightly larger share of women than men agreed (44.4\% and $39.6 \%$, respectively), and agreement was expressed by more people from a lower class than a higher class, the differences are not pronounced and significant, but reveal a pessimistic attitude to the future of public health care in Slovenia in general. When asked "How many people do you think have no access to the health care they need « as many as $51 \%$ of the respondents thought "some «, and $20 \%$ thought »many «. Only $19.5 \%$ of the respondents thought there are no or very few of such people. This belief is worrying because it reflects people's subjective perception of the state of affairs and their fear concerning the future of health care in Slovenia.

\section{CONCLUSION}

Due to the rising health care costs, the key problem of both health policies and individuals is how to stay healthy for as long as possible. The most frequent answer of modern health policies is emphatically (neo) liberal - the individualisation of care for health. Health promotion activity that focuses on diet, smoking and exercise without addressing poverty, social isolation, gender roles in caregiving, socio-economic inequalities, occupational and household hazards and environmental pollution will not be in women's best interest (4). Critical analyses of health care systems call attention to the fact that quicker solutions are to be found in reducing social differences and providing access to health services for everyone $(23,15)$. Welfare states are important determinants of health and health (in)equalities as they mediate the extent and impact of the socio-economic position on health $(24,1)$.

So far, in debates about changes of health care policies in Slovenia, little attention has been paid to the effects of the neoliberal reforms of health care for women. Neoliberal economic reforms (of health care) affect vulnerable social categories the most, and women are particularly exposed. The market does not recognise gender differences in the economy or family relations, which still burden women more than men. The use of women's unpaid work in the family belongs among the basic (neo)liberal saving strategies. These want to take more care and health work within families from the shoulders of the state and place it on the shoulders of family members, which mainly means women.

The persistent reduction of social transfers as a way of solving the economic crisis, the cutting of maternity leave allowances, the abolition of subsidies on school food, the reduction of child benefits and the lowering of pensions means that the state is shifting the responsibility of the state and local communities for survival and well-being to the family - meaning mostly women. This activity is commonly disguised in the motto of promoting greater voluntary "participation « of 
people in the offer of health care services at the basic level. In insecure and crisis social conditions, this helps exacerbate the position of women compared to men. In these circumstances, it is understandable that women subjectively assess their health as being worse than men's. Moreover, conditions are being established that will de facto actually lead to worse health in the female population in Slovenia.

Therefore, a more just health system is needed than that offered by the neoliberal vision, and not only for the sake of justice but also for the sustainability and quality of life of the entire population (25). The data shows that people in Slovenia consensually speak in favour of a public health care system that would be based on equality, accessibility and justice for all. That is, a system that recognises the gender-specific health needs of women and men, and prevents inequalities in health care whereby women are given a greater burden and at the same time a smaller degree of recognition for their important care work. The survey respondents spoke in favour of balancing the distribution and the recognition elements of equality in the health care system. The distribution elements include e.g. geographic accessibility to health care services, the economical accessibility of services for all, the equal distribution of work in providing health care between men and women, the inclusion of different health care needs of people and the provision of equal quality health services for all. The recognition elements include a respect for individual differences between patients, the equal valuation of care work (which usually falls on women) and traditional unpaid work, the recognition of different health needs according to individuals' social position, the maintenance of common humanness and the inclusion of patients as actors rather than objects of health services.

This public opinion image of people's attitude to health care leads us to conclude that focusing health policy measures on individuals' attitudes to health and to the doctor-patient relationship would be an erroneous strategy. Namely, it would deepen the insecurity by individualising the burden of care for health - making the patient and the doctor bear its weight. The patient-doctor relationship and the individualisation of care for one's own health only reduce the insecurity of individuals in such an important field as health to a small extent. A key factor of security is equal access to health services. Equality can be achieved in a society sensitised to the question of equality by providing more support to the most vulnerable social categories, and not with the simple provision of formal equality and even less so with the liberalisation of social subsystems (such as health care and education). Formal equality overlooks essential differences in access to social systems and their services for the most vulnerable social categories of the population, and the liberalisation of social subsystems only sees »equality « in all individuals being equally responsible for shouldering the strain of life and care for their own well-being, while overlooking the fact that differences in engagement or readiness and capability to cope with the strain of their life between specific categories of individuals are structurally determined.

\section{References}

1. Bambra C, Eikemo TA. Welfare state regimes, unemployment and health: a comparative study of the relationship between unemployment and self-reported health in 23 European countries. J Epidemiol Community 2009; 63: 92-98.

2. Crimmins EM, Kim JK, Sole'-Auro A. Gender differences in health: results from SHARE, ELSA and HRS. Eur J Public Health 2010; 21: 81-91.

3. Walters V, Lenton R, McKeary M. Women's health in the context of women's lives. Ottawa: Minister of supply and services Canada, 1995.

4. Denton M, Walters V. Age differences in women's perceptions of their health problems and concerns. Hamilton: MC Master University, 1997.

5. Malnar B. Trendi neenakosti v Sloveniji med statistiko in javnim mnenjem. Teor Praksa 2011; 4: 951-967.

6. Whitehead M, Dahlgren G. Levelling up (part 1): a discussion paper on concepts and principles for tackling social inequalities in health. Copenhagen: WHO, Regional Office for Europe, 2006.

7. Whitehead M, Dahlgren G. Levelling up (part 2): a discussion paper on European strategies for tackling social inequalities in. Copenhagen: WHO, Regional Ofice for Europe, 2006.

8. Turner BS. The body and society: explorations in social theory. London: Sage, 1996.

9. Lupton D. Medicine as culture: illness, disease and the body in western societies. London: Sage, 1994.

10. Radley A. Making sense of illness. London: Sage, 1995.

11. Grosz E. Volatile bodies: toward a corporeal feminism. Sydney: Allen and Unwin, 1994.

12. Ziglio E, Barbosa R, Charpak Y, Turner S. Health systems confront poverty. Copenhagen: WHO, 2003.

13. Ewig C. Second wave neoliberalism: gender, race, health sector reform in Peru. Pennsylvania: Pennsylvania State University, 2010.

14. Mencin Čeplak M, Hlebec V. Trust in an individual physician and its contradictions. Zdrav Var 2012; 51: 53-68.

15. Macintyre S, Hunt K, Sweeting H. Gender differences in health: are things really as simple as they seem? Soc Sci Med 1996; 42: 617-624.

16. Macintyre S, McKay L, Ellaway A. Are rich people or poor people more likely to be ill?: lay perceptions, by social class and neighbourhood of inequalities in health. Soc Sci Med 2005; 60: 313-317.

17. Anderson NB, Armstead CA. Toward understanding the association of socioeconomic status and health: a new challenge for the biopsychosocial approach. Psychosom Med 1995; 57: 213-225.

18. Malnar B. et al. Slovensko javno mnenje 2011/1. Ljubljana: Fakulteta za družbene vede, 2011. 
19. ISSP project. Available from: www.issp.org.

20. Wilkinson R. Unhealthy society. Routledge, 1996.

21. Leskošek V. Social determinants of health: the indicators for measuring the impact of poverty on health. Zdrav Var 2012; 51: 21-32.

22. Baxter M. Health and lifestyles. London: Tavistock/Routledge, 1990.

23. Anker T, Kamin T. Health branding ethics. J Buss Ethics 2011; 104: 33-45.

24. Malnar B, Kurdija S. Trends in subjective health assessment between 1981 and 2011 as an indicator of persistent social inequalities. Zdrav Var 2012; 51: 11-20.

25. Albreht $\mathrm{T}$, Klazinga N. Balancing equity and efficiency through health care policies in Slovenia during the period 1990-2008 Zdrav Var 2010; 49: 49-60.

\section{(Endnotes)}

1 ANOVA Group difference sig. level: Education (sig. 0.000), Income (sig. 0,000) Age (sig. 0,000), Class (sig. 0,000).

2 ANOVA Group difference sig. level: Education (sig. 0.001), Age (sig. 0,001), Nationality (sig. 0,049).

3 ANOVA Group difference sig. level: Class (sig. 0.035).

4 ANOVA Group difference sig. level: Region (sig. 0.009).

5 ANOVA Group difference sig. level: Age (sig. 0.017). 